\title{
Pemantauan Jumlah Bakteri Coliform Di Perairan Sungai Provinsi Lampung
}

\author{
Rizki Adrianto \\ Balai Riset dan Standardisasi Industri Bandar Lampung \\ Jl by pass Soekarno Hatta KM 1 Rajabasa \\ E-mail : Rizki1083@gmail.com
}

\begin{abstract}
Abstrak
Coliform merupakan golongan mikroorganisme yang lazim digunakan sebagai indikator dimana bakteri ini dapat menjadi sinyal untuk menentukan suatu sumber air telah terkontaminasi oleh patogen atau tidak. Salah satu penyebab terjadinya pencemaran air adalah mikrooganisme patogen yang terkandung dalam tinja karena dapat menularkan berbagai macam penyakit apabila masuk kedalam tubuh manusia. Penelitian ini bertujuan untuk mengetahui jumlah bakteri coliform di Sungai Provinsi Lampung di 8 Lokasi pengambilan titik sampling. Metodologi yang digunakan dalam penelitian ini adalah Pengambilan sampel dan survey lapangan, wawancara, serta analisis laboratorium. Hasil Pengujian menunjukkan jumlah koliform tertinggi terdapat pada lokasi Sungai I berkisar antara 25394-24413 JPT/100 mL, terendah terdapat pada lokasi Sungai VII berkisar antara 8564-12034 JPT/100 mL Hasil pengujian menunjukkan perairan Sungai Provinsi Lampung tercemar bakteri coliform yang telah melewati ambang batas persyaratan sungai kelas I (1000 Jumlah/100mL).
\end{abstract}

Kata Kunci : Coliform, Sungai Provinsi Lampung, Jumlah bakteri

\section{Pendahuluan}

Air merupkan kebutuhan dasar hidup di bumi yang menentukan kesehatan dan kesejahteraan manusia (Cahyadi et, al, 2011; Sumantri, 2013). Salah satu sumber air tawar dengan potensi yang besar adalah sungai.

Sungai adalah aliran air alami dari daerah hulu ke daerah hilir. Aliran alami sungai merupakan sumber utama untuk memenuhi air bagi manusia (Asdak, C., 2003). Sungai merupakan wadah air alami sebagai penyedia air dan wadah air untuk memenuhi kebutuhan rumah tangga, sanitasi lingkungan, pertanian, industri, pariwisata, olahraga, pertahanan, perikanan, pembangkit tenaga listrik dan transportasi (PPRI Nomor 38 Tahun 2011)

Sungai banyak dijadikan sebagai tempat pembuangan kotoran dan sampah terutama pada kota-kota besar (Indarsih dkk., 2011; Soolikhah dkk., 2014)). Salah satu penyebab terjadinya pencemaran air adalah mikrooganisme patogen yang terkandung dalam tinja karena dapat menularkan berbagai macam penyakit apabila masuk kedalam tubuh manusia. Dampak limbah ini akan semakin terlihat pada saat musim kemarau dikarenakan volume debit air sungai mengalami penurunan sehingga kemampuan pengenceran air sungai terhadap limbah domestik juga menurun. Aktivitas penduduk yang semakin meningkat di sepanjang aliran sungai di Provinsi Lampung, seperti bertambahnya pemukiman penduduk, keberadaan pasar, rumah sakit, dan lain-lain

Data Dinas Kesehatan Provinsi Lampung menunjukkan angka kejadian diare pada tahun 2017, mencapai 219.167 penderita. Hal ini menunjukan bahwa masalah air tercemar limbah domestik lebih besar karena coliform yang ada dalam limbah dan perilaku hidup masyarakat yang kurang sehat. Tingginya indikasi limbah domestik sebagai penyebab penyakit ini, didasarkan pada parameter pengukuran kualitas limbah perairan Sungai di Provinsi Lampung terhadap potensi resikonya terhadap lingkungan. Kandungan mikroorganisme yang tinggi seperti Coliform, Escherichia coli, Streptococus faecalis, Vibrio cholera, berbagai jenis virus dan kutu cacing yang terdapat dalam air limbah domestik merupakan penyebab dari penularan penyakit-penyakit tersebut.

Coliform merupakan golongan mikroorganisme yang lazim digunakan sebagai indikator, di mana bakteri ini dapat menjadi sinyal untuk menentukan suatu sumber air telah 
terkontaminasi oleh patogen atau tidak. Berdasarkan penelitian, bakteri koliform ini menghasilkan zat etionin yang dapat menyebabkan kanker. Selain itu, bakteri pembusuk ini juga memproduksi bermacammacam racun seperti indol dan skatol yang dapat menimbulkan penyakit bila jumlahnya berlebih di dalam tubuh. Bakteri koliform dapat digunakan sebagai indikator karena densitasnya berbanding lurus dengan tingkat pencemaran air. Bakteri ini dapat mendeteksi patogen pada air seperti virus, protozoa, dan parasit. Selain itu, bakteri ini juga memiliki daya tahan yang lebih tinggi daripada patogen serta lebih mudah diisolasi dan ditumbuhkan (Prayitno, 2009)

Penelitian mengenai pemantauan jumlah bakteri coliform di air sungai Provinsi Lampung belum pernah dilakukan akan tetapi terdapat data pendukung dari penelitian ini yang berjudul kepadatan bakteri coliform di sungai Kapuas kota Pontianak (Khotimah, 2013), Analisis kandungan bakteri Fecal coliform pada Sungai Kuin kota Banjarmasin (Arsianty dkk, 2017)

\section{Metode Penelitian}

Penelitian dilakukan di Sungai yang terdapat di Bandar Lampung, Lampung Selatan, Lampung Tengah, Lampung Timur, Lampung Utara, Pesawaran, Pringsewu, Way Kanan, Provinsi Lampung, dan di Laboratorium Mikrobiologi Baristand Industri Bandar Lampung. Penelitian berlangsung selama 6 bulan dari bulan April sampai bulan Oktober 2017.

Alat-alat yang digunakan pada penelitian ini adalah botol steril, erlenmeyer, beker glass, gelas ukur, tabung reaksi, tabung durham, rak tabung, kapas penutup, cawan petri, spatula, autoklaf, oven/inkubator, bunsen, makro dan mikropipet, ose, mikroskop, pinset, gelas objek, hot plate, kertas label, aluminium foil, alat tulis, $\mathrm{pH}$ meter, termometer, dan kamera.

Bahan-bahan yang digunakan pada penelitian ini antara lain: sampel air sungai, akuades steril, alkohol 70, larutan Natrium tiosulfat 0,025 N, media Lactose Broth (LB), media Briliant Green Lactose Bile Broth (BGLBB), BPW (Buffer Phospate Water)
Pengambilan sampel dilakukan dengan metode purposive random sampling berdasarkan perbedaan rona lingkungan. Berdasarkan metode tersebut ditentukan 4 lokasi sampling per hari.

\section{Pengambilan sampel}

Menurut Khotimah

(2013),

Pengambilan sampel air sungai dilakukan dengan metode komposit sampel sebanyak 3 kali di masing-masing lokasi kemudian di campur dan di homogenkan. jarak yang dilakukan untuk pengambilan 5 meter dengan menggunakan botol steril dengan cara bagian mulut botol dibakar terlebih dahulu untuk menghindari masuknya mikroorganisme selain dari air, kemudian dicelupkan searah dengan arus air, selanjutnya mulut botol dan tutup botol dibakar kembali.

\section{Pengukuran Fisik Lapangan}

Pengukuran lapangan dilakukan secara eksitu. Parameter fisik yang dilakukan pengujian antara lain $\mathrm{pH}$ dan suhu. pengukuran $\mathrm{pH}$ digunakan $\mathrm{pH}$ meter dan pengukuran suhu digunakan dengan thermometer batang ( $\mathrm{Hg}$ ) dengan skala $0-150{ }^{\circ} \mathrm{C}$.

\section{Pengukuran Kimia}

Parameter kimia air yang diukur pada saat pengambilan sampel kandungan oksigen $\left(\mathrm{O}_{2}\right)$ terlarut dengan menggunakan metode Potensio meter dengan DO meter, PTT ( Padatan Terlarut Total) dengan menggunkan metode SNI 06-6989-.3-2004, BOD5 (Biologycal Oxygen Deman) dengan menggunakan metode SNI 6989.72:2009.

\section{Pengukuran Bakteri Coliform dengan Metode MPN (SNI 06-4158-1996)}

Pemeriksaan terhadap bakteri coliform dilakukan dalam 4 tahapan, yaitu tes pendahuluan (persumtive test), tes penegasan (confirmative test), tes pelengkap (complete test).

\section{Tes Pendahuluan (Persumtive Test)}

Sebanyak $9 \mathrm{ml}$ media Lactose Broth (LB) dimasukkan ke dalam tabung reaksi yang telah diisi tabung durham. Tabungtabung tersebut disterilisasi dengan autoklaf pada suhu $121^{\circ} \mathrm{C}$ 
selama 15 menit. Sampel air yang akan diperiksa diencerkan dengan menambahkan $9 \mathrm{ml}$ aquades steril dengan $1 \mathrm{ml}$ sampel air sungai sehingga diperoleh pengenceran 10-1. Pengenceran secara berturut-turut dengan tingkatan diambil dari 0,1 $\mathrm{ml}, 0.01 \mathrm{ml}, 0.001 \mathrm{ml}$ dan dimasukkan ke dalam media LB masing-masing sebanyak 3 tabung. Tabung-tabung tersebut kemudian disimpan dalam inkubator pada suhu $37^{\circ} \mathrm{C}$ selama 24-48 jam. Keberadaan coliform ditandai dengan terbentuknya gas atau asam (terjadi perubahan warna).

\section{Tes Penegasan (Comfirmative Test)}

Sebanyak 1-2 ose suspensi dari tes pendahuluan (persumtive test) yang positif diinokulasikan ke dalam tabung yang berisi media Briliant Green Lactose Bile Broth (BGLBB). Tabung-tabung tersebut diinkubasikan pada suhu $37^{\circ} \mathrm{C}$ selam $24-48$ jam. Keberadaan coliform juga ditandai dengan terbentuknya gas atau asam atau terjadi perubahan warna. Jumlah bakteri coliform pada tes penegasan dihitung berdasarkan metode MPN.

\section{Tes Pelengkap (Complete Test)}

Salah satu media yang positif pada tes penegasan (confirmative test) diinokulasikan sebanyak 1 ose ke dalam media Eosine Metilene Blue (EMB) agar, kemudian diinkubasi pada suhu $37^{\circ} \mathrm{C}$. Setelah 3-4 hari masa inkubasi, bila koloni tumbuh dengan ciri-ciri berwarna hijau kehitaman metalik dilanjutkan dengan uji biokimia dan dilakukan pewarnaan gram.

Analisis Data Kepadatan bakteri coliform dihitung sesuai SNI 06-4158-1996 dengan rumus :

Jumlah Total Bakteri Koliform (JPT/100 mL) =

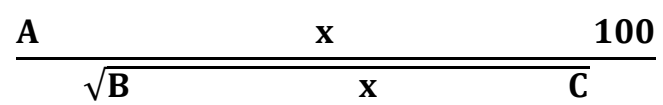

Keterangan:

A= Jumlah tabung yang positif

$\mathrm{B}=$ Volume $(\mathrm{mL})$ benda uji dalam tabung yang negative

$\mathrm{C}=$ Volume $(\mathrm{mL})$ benda uji dalam semua tabung

\section{Hasil Dan Pembahasan}

Bakteri Coliform adalah bakteri indikator keberadaan bakteri patogenik lain.
Lebih tepatnya bakteri Coliform fecal adalah bakteri indikator pencemar bakteri patogen. Contoh bakteri coliform adalah Escherichia coli dan Enterobacter aerogenes, makin sedikit kandungan coliform artinya kualitas air semakin baik (Friedheim et., al., 2001). Hasil penelitian ini dilakukan dari bulan April sampai bulan Oktober 2017.

Hasil penelitian selama bulan April sampai dengan Oktober 2017 menunjukkan total coliform pada 8 Sungai pengamatan yang dilakukan di Sungai Provinsi Lampung berdasarkan pengambilan sampel awal dan pengambilan sampel akhir, ditunjukkan pada tabel 1 berikut.

Tabel 1. Rata-rata Jumlah Kepadatan Coliform di Sungai Provinsi Lampung Pada Bulan April-Oktober 2017

\begin{tabular}{llll}
\hline No & Sungai & $\begin{array}{l}\text { Pengambilan } \\
\text { Awal* } \\
\text { (JPT/100 } \\
\text { mL) }\end{array}$ & $\begin{array}{l}\text { Pengambilan } \\
\text { Akhir* } \\
\text { (JPT/100 } \\
\text { mL) }\end{array}$ \\
\hline 1 & I & 24413 & 15394 \\
2 & II & 24123 & 12414 \\
3 & III & 27132 & 3659 \\
4 & IV & 11682 & 3700 \\
5 & V & 12597 & 11140 \\
6 & VI & 19856 & 9760 \\
7 & VII & 12034 & 8564 \\
8 & VIII & 17366 & 15276 \\
\hline
\end{tabular}

Keterangan:

I = Pesawaran, Pagelaran, Banyuwangi, Pujorahayu, Gadingrejo, Batu tegi, Gedung Tataan, Kalirejo, Bangun rejo, Tegineneng,

II = Lampung Selatan, Sidomulyo, Tegalega, Sindang sari,

III = Teluk betung, segalamider, Sukaraja

IV = Marga Sekampung, Sukadana, Way Jepara, Pugung Raharjo, Curup Mataram, Labuhan Maringgai,

Pekalongan, Raman Utara,Pasir sakti,V = Bandar Sari, Pubian, Segalamider, Bekri, gunung sugih, Terbanggi Besar, Gunung Batin, selagai lingga, padang ratu, mataram udik, bangun rejo, banjar agung, ajibaru, kalirejo

VI = Tubaba, Tulang bawang, Mesuji, Bandar sari, Bujuk Agung, Menggala, Tulung mas 
VII = Pekurun, Abung barat, ogan enam, Banjarmasin, negri batin, blambangan umpu, reabang tangkas, rebang tangkas kasui, kotabumi selatan, sungkai tengah, banjit, rantau temiang, sungkai tengah, kotabumi, pakuan ratu

VIII = Sumber jaya, Banjarsari

* $\quad$ = Bulan April sampai Juli (Hujan/Banjir)

* $\quad=$ =Bulan Agustus sampai Oktober

(Panas/kemarau)

Tabel 1 menunjukkan adanya kepadatan bakteri Coliform saat Pengambilan awal dan akhir di setiap sungai. Menurut, perbedaan kepadatan Coliform antar sungai pengambilan sampel air disebabkan perbedaan rona lingkungan sungai pengambilan sampel, arah arus air dan ketinggian air sungai.

\section{Jumlah Kepadatan Bakteri Fecal Coliform Berdasarkan Lokasi Pengambilan}

Kepadatan total bakteri koliform yang paling tinggi terdapat di Sungai III pada pengambilan awal sebesar 27132 JPT/100 mL. Hal tersebut dikarenakan pada wilayah ini terdapat kepadatan tempat tinggal penduduk, sehingga banyak kegiatan yang dilakukan di sekitar sungai tersebut Antara lain untuk mandi dan mencuci pakaian. Menurut Feliatra (2002), pengaruh limbah rumah tangga seperti feses atau sisa makanan lainnya masih mendominasi sebagai faktor penyebab pencemaran lingkungan air.

Lokasi pemukiman padat penduduk dengan kerapatan penduduk yang tinggi, jarak antara satu rumah dengan rumah yang lain sangat dekat, jarak antara pembuangan limbah rumah tangga dan septic tank dengan sumber air cenderung berdekatan serta kebiasaan penduduk di tepian sungai membuang urine dan feses secara langsung ke sungai menyebabkan terjadinya pencemaran bakteri coliform. Khotimah (2013) menyatakan bahwa kandungan bakteri fecal coliform tinggi pada saat surut dibandingkan saat pasang. Hal ini sesuai dengan hasil penelitian ini yang menunjukkan pola yang sama. Kandungan bakteri juga dipengaruhi oleh volume air. Saat volume air tinggi mempunyai kadar bakteri tidak sebesar pada saat volume air menurun.

\section{Hubungan Kondisi Fisika Kimia Sungai Provinsi Lampung dengan Keberadaan Bakteri Coliform}

Hasil pengukuran parameter fisika kimia pada kedelapan sungai pengamatan di Provinsi Lampung dapat dilihat pada Tabel 2. Suhu dan $\mathrm{pH}$ merupakan faktor lingkungan yang sangat menentukan kehidupan mikroorganisme karena pengaruh suhu berhubungan dengan aktivitas enzim. pH merupakan derajat keasaman yang digunakan untuk mengukur nilai keasaman atau kebasaan dari suatu cairan sehingga kita mampu mengetahui kelayakan dari cairan tersebut.

Air merupakan komponen yang sangat penting bagi semua makhluk hidup yang ada didunia ini termasukikan. Pada umunya perairan alami mempunyai pH sekitar 6 sampai 9 . Menurut Anonim (2018) Derajat asam penting bagi kehidupan ikan,air disungai juga sangat bermanfaat bagi kehidupan manusia yang dimanfaatkan untuk dikonsumsi maupun untuk memenuhi kebutuhan hidup sehari- hari. Jadi selain memakai kita juga harus menjaga sungai dengan jangan membuang sampah sembarangan disungai. Maka kita perlu mengukur $\mathrm{pH}$ pada air sungai jika air sungai memiliki jumlah $\mathrm{pH}$ yang tidak normal maka kita tidak dapat memakai air sungai tersebut untuk dikonsumsi karena dikhawatirkan dapat mengakibatkan keracunan.

Tabel 2. Rata-rata Parameter Fisika Kimia Sungai di Provinsi Lampung

\begin{tabular}{|c|c|c|c|c|c|c|c|c|c|c|c|c|c|c|c|c|}
\hline \multirow{2}{*}{$\begin{array}{l}\text { Param } \\
\text { eter }\end{array}$} & \multicolumn{8}{|c|}{ Pengambilan awal } & \multicolumn{8}{|c|}{ Pengambilan Akhir } \\
\hline & I & II & III & IV & V & VI & VII & VIII & I & II & III & IV & $\mathbf{V}$ & VI & VII & VIII \\
\hline Suhu & 29,2 & 31,2 & 30,2 & 30,1 & 29,2 & 31,2 & 27,2 & 32 & 29,1 & 29,2 & 30,2 & 30,1 & 30,2 & 31 & 29,3 & 26,3 \\
\hline $\mathrm{pH}$ & 7,30 & 7,43 & 7,38 & 6,72 & 6,73 & 6,24 & 7,45 & 8,14 & 7,28 & 7,04 & 7,38 & 6,77 & 6,89 & 7,25 & 8,13 & 7,23 \\
\hline DO & 6,24 & 5,72 & 6,53 & 6,27 & 6,33 & 5,98 & 7,90 & 7,83 & 6,23 & 6,69 & 6,53 & 5,29 & 6,89 & 8,03 & 6,21 & 6,04 \\
\hline BOD5 & 2 & 2 & $<2$ & 15 & 7 & 2 & 4 & 2 & 3 & 5 & $<2$ & $<2$ & 2 & $<1$ & 3 & 2 \\
\hline PTT & 128 & 205 & 133 & 81 & 278 & 83 & 142,5 & 120 & 174 & 214 & 133 & 93 & 93 & 103 & 89 & 51 \\
\hline
\end{tabular}


Menurut Supardi dan Sukamto (1999), suhu rendah menyebabkan aktivitas enzim menurun dan jika suhu terlalu tinggi dapat mendenaturasi protein enzim. Berdasarkan pengukuran yang dilakukan pada kedelapan sungai pengamatan, suhu air Sungai rata-rata berkisar antara 26,3-30,2 ${ }^{\circ} \mathrm{C}$. Suhu optimum untuk pertumbuhan bakteri coliform adalah 37 ${ }^{0} \mathrm{C}$ (Sayuti dkk., 2005; Hidayati dkk., 2006).

Berdasarkan hasil penelitian pada tabel 3 menunjukkan $\mathrm{pH}$ dan suhu yang dihasilkan di setiap sungai relatif stabil. Berdasarkan suhu optimum pertumbuhannya, Supardi dan Sukamto (1999) mengelompokkan bakteri menjadi 3 yaitu : psikrofilik $\left(0-20{ }^{\circ} \mathrm{C}\right)$, mesofilik $\left(20-50{ }^{\circ} \mathrm{C}\right)$ dan termofilik $\left(50-100{ }^{\circ} \mathrm{C}\right)$. Bakteri coliform yang ditemukan di Sungai Provinsi Lampung merupakan bakteri kelompok mesofilik dilihat dari suhu air pada saat pengambilan sampel. Dari pengamatan kualitas air di 8 lokasi sungai, ditemukan beberapa parameter kimia yang tidak masuk nilai baku mutu berdasarkan Sungai kelas I berdasarkan PP No. 82 tahun 2001, diantaranya adalah BOD dan PTT. Tingginya nilai BOD dan PTT yang terkandung dalam air sungai di 8 lokasi sungai menunjukan banyaknya bahan organik yang dapat didegradasi secara biologis maupun yang sukar didegradasi secara biologis seperti tumbuhan dan hewan yang telah mati, hasil buangan limbah domestik dan industri.

Nilai BOD pada lokasi pengambilan awal lokasi sungai 1-8 secara berurutan adalah 2,2 , $<2,15,7,2,4,2 \mathrm{mg} / \mathrm{L}$ yang dapat dilihat pada Tabel 2 sedangkan pada 8 lokasi sungai pada pengambilan akhir secara berurutan adalah 3,5 , $<2,<2,2,<1,3,2 \mathrm{mg} / \mathrm{L}$. Hal ini berkitan dengan banyaknya kadar oksigen yang dibutuhkan oleh mikroba untuk mengoksidasi bahan pencemar organik menjadi karbondioksida (CO2) dan air (H20) (Effendi, 2003). Sedangkan PTT yang diperoleh dari hasil pengamatan dari 8 lokasi sungai pengambilan awal adalah $128,205,133$, $81,278,83,142,5,120 \mathrm{mg} / \mathrm{L}$ dan pada pengambilan akhir hasilnya $174,214,133,93,93$, 103, $89,51 \mathrm{mg} / \mathrm{L}$. Hal ini berhubungan dengan residudari padatan total yang tertahan oleh saringan dengan ukuran partikel maksimal $2 \mu \mathrm{m}$ atau lebih besar dari ukuran partikel koloid. Yang termasuk TSS adalah lumpur, tanah liat, logam oksida, sulfida, ganggang, bakteri dan jamur (Effendi, 2003).

Parameter kimia lain yang tidak melebihi nilai baku mutu adalah $\mathrm{pH}$, suhu dan Dissolved Oxygen (DO). pH dan suhu air Sungai di Provinsi Lampung dikategorikan sebagai suhu dan $\mathrm{pH}$ normal yaitu $26,3-31,2^{\circ} \mathrm{C}$ dan $6,24-$ 8,14 . Sebagian besar biota akuatik dapat hidup dengan baik pada kondisi $\mathrm{pH}$ ini. Nilai pH dapat mempengaruhi toksisitas suatu senyawa kimia, semakin tinggi nilai $\mathrm{pH}$ maka nilai alkalinitas semakin tinggi dan kadar karbondioksida semakin rendah (Effendi, 2003). Jika pH rendah, maka perairan tersebut bersifat asam dan korosif, toksisitas logam mengalami peningkatan, serta proses nitrifikasi akan terhambat (Effendi, 2003). Sedangkan kadar oksigen terlarut (DO) dalam air adalah baik yaitu $>5 \mathrm{mg} / \mathrm{l}$. Hal ini menunjukan bahwa tidak adanya aktifitas pertanian yang intensif pada area ini mengingat sisa pupuk merupakan salah satu sumber bahan pencemar ini. Berdasarkan Paco et al., (2003),

Faktor lingkungan yang paling sensitif dan berpengaruh terhadap pertumbuhan mikroorganisme khususnya bakteri adalah keberadaan Oksigen. Contohnya, beberapa mikroorganisme dapat tumbuh hanya jika ada 02 yang disebut aerob obligat. Fakultatif anaerob dapat tumbuh jika tidak ada 02 tetapi dapat tumbuh lebih baik bila ada 02 .

\section{Kesimpulan}

Kepadatan bakteri coliform di Sungai di Provinsi Lampung adalah sebagai berikut;

a. Sungai I pengambilan awal 24413 JPT/100 mL, pengambilan akhir 15394 JPT $/ 100 \mathrm{~mL}$,

b. Sungai II pengambilan awal 24123 JPT/100mL, pengambilan akhir 12414 JPT/100 mL,

c. Sungai III pengambilan awal 27132 JPT/100 mL, pengambilan akhir 3659 JPT/100 mL,

d. Sungai IV pengambilan awal 11682 JPT/100 mL, pengambilan akhir 3700 JPT $/ 100 \mathrm{~mL}$,

e. Sungai $\mathrm{V}$ pengambilan awal 12597 JPT/100 mL, pengambilan akhir 11140 JPT/100 mL, sungai VI pengambilan 
awal $19856 \mathrm{JPT} / 100 \mathrm{~mL}$, pengambilan akhir 9760 JPT/100 mL,

f. Sungai VII pengambilan awal 12034 JPT/100 mL, pengambilan akhir 8564 JPT/100 mL,

g. Sngai VIII pengambilan awal 17366 JPT/100 mL, pengambilan akhir 15276 JPT/100 mL dan berdaarkan sungai kelas I hasilnya sebagian besar melewati standar baku mutu yang ditetapkan oleh PP Nomor 82 tahun 2001 tentang pengelolaan kualitas air dan pengendalian pencemaran air.

Air Sungai Sungai di Provinsi Lampung rata-rata tidak layak untuk dikonsumsi sebagai air bahan baku air minum sesuai PP No. 82 Th. 2001 tentang persyaratan air minum yaitu 1000 MPN/100 mL berdasarkan sungai kelas I.

\section{Daftar Pustaka}

Adack, J. 2013. Dampak Pencemaran Limbah Pabrik Tahu Terhadap Lingkungan Hidup. Lex Administratum Vol. I Juli-September No. 3.

Arsianty D., Adyatma A., Huda N., 2017, Jurnal Analisis Kandungan Bakteri Fecal Coliform Pada Sungai Kuin Kota Banjar masin, Fakultas Geografi Universitas Gadjah Mada, Yogyakarta.

Cahyadi, A., Priadmodjo, A. \& Yananto, A. (2011). Criticizing The Conventional Paradigm of Urban Drainage. Proceeding The 3rd International Graduated Student Conference on Indonesia. Yogyakarta: Sekolah Pascasarjana Universitas Gadjah Mada.

Effendi, H. 2003. Telaah Kualitas Air bagi Pengelolaan Sumber Daya dan Lingkungan Perairan. Cetakan Kelima. Yogjakarta : Kanisius.
Feliatra, 2002, Sebaran Bakteri Escherichia coli di Perairan Muara Sungai Bantan Tengah Bengkalis Riau, Fakultas Perikanan dan Kelautan, Universitas Riau ,Pekanbaru. Jur. Biogen. 1. 178-18.

Friedheim. 2001. Bacteriological Analytical Manual. John Wiley \& Sons Inc. New York. Dikutip dari tulisan Hariyono Purbowarsito. 2011. Uji Bakteriologis Air Sumur di Kecamatan Semampir Surabaya. Fakultas Sains dan Teknologi Universitas Airlangga : Surabaya.

Hidayati, Y.A.; Harlia, E. dan Suryanto, D., 2006, Deteksi Jumlah Total Bakteri dan Coliform pada Kompos Kotoran Domba Sebagai Indikator Sanitasi Lingkungan, Fakultas Peternakan, Lokakarya Nasional Keamanan Pangan Produk Peternakan, Universitas Padjadjaran, Bandung

Indarsih, W., Suprayogi, S. \& Widyastuti, M. (2011). Kajian Kualitas Air Sungai Bedog Akibat Pembuangan Limbah Cair Sentra Industri Batik Desa Wijirejo. Majalah Geografi Indonesia, 25(1), 40-54.

Khotimah, S, (2013), Kepadatan Bakteri Coliform di Sungai Kapuas Kota Pontianak. Prosiding Semirata. Bandar Lampung: Fakultas Matematika dan Ilmu Pengetahuan Alam Universitas Lampung.

Peraturan Pemerintah Nomor 38 Tahun 2011, tentang Sungai.

Peraturan Pemerintah No. 82 Th. 2001 tentangPengelolaan Kualitas Air dan Pengendalian Pencemaran Air

Prayitno, A. (2009). Uji Bakteriologi Air Baku dan Siap Konsumsi dari PDAM Surakarta Ditinjau dari Jumlah Bakteri Coliform. Skripsi. Surakarta: Universitas Muhammadiyah Surakarta. (Online) (http://eprints.ums.ac.id/3821/1/A42004 0040.pdf diakses 3 Oktober 2015).

Sayuti, I.; Wulandari, S. \& Fatimah, S., 2005, Bakteri Enterik dalam Minuman Jamu Gendong di Kota Pekanbaru, PMIPA, FKIP, Universitas Riau, Pekanbaru, Biogen. 2(1), 16-19. 